\title{
Genres and Their Implications: Meddlesomeness in On Curiosity versus the Lives $^{1}$
}

\author{
Lieve Van Hoof
}

The Lives, so it is stressed over and over again, have an ethical aim. And so do, obviously, the Moralia, or at least the group of writings within that corpus which Ziegler (col. 637) labelled Plutarch's "popularphilosophisch-ethischen Schriften." It is often interesting and instructive to compare Plutarch's treatment of one and the same virtue or vice in both groups of works, as has recently been done, for example, concerning anger. ${ }^{2}$ Yet on the other hand some of the vices Plutarch dedicated a whole work of the Moralia to do not

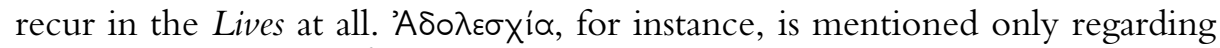
Alexander in the Lives, ${ }^{3}$ and then does not have the same, negative sense it has in On Talkativeness. Or again, it is said only once of a protagonist that he is

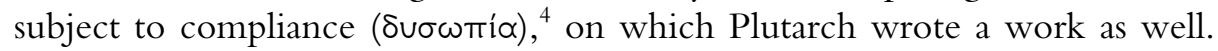
Why, then, did Plutarch find these vices important enough to write a whole treatise about them, and why do they receive little to no attention in the Lives ? ${ }^{5}$

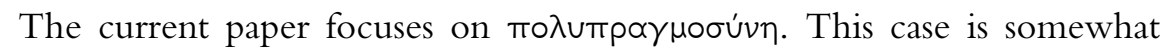

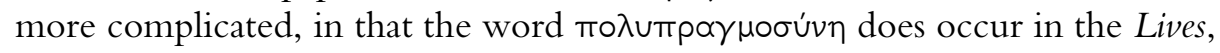
yet it is never, as will be shown, applied to a protagonist in the sense it has in On Curiosity. ${ }^{6}$ In a first part, this paper therefore analyses what exactly Plutarch

1 I wish to thank Prof. Dr. L. Van der Stockt and Prof. Dr. T. Whitmarsh, as well as Dr. P. Van Nuffelen, Dr. S. Verdegem, and J. Zeedijk for their useful comments on (earlier versions of) this paper.

2 See, for example, Nikolaidis 1991, 172; Alexiou, 101-113; Duff, 87-89 and 210215.

3 Life of Alexander 23.7.

4 Viz. Solon 14.7. Note that in Brutus 6.9, Plutarch has the protagonist deem nothing more disgraceful than to be subject to compliancy.

5 The terminus post quem for On Curiosity is Domitian's death in 96. See Jones, 72. Dumortier - Defradas, 263 assign the work to "l'époque de Trajan", Inglese 1996, 29 30 talks about "tra il 100 e il 120", taking into account the relative chronology. Although it therefore cannot be counted among the early works of Plutarch, many of

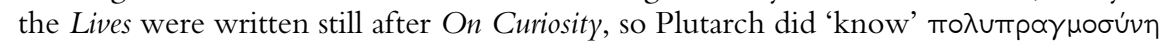
as intended in On Curiosity when writing at least some of the Lives.

6 The work, number 97 in the Catalogue of Lamprias, has not been treated often or extensively by scholars in the past. Known to me are, except for the - mostly short introductions accompanying the editions of Helmbold, Dumortier - Defradas, Pettine, 


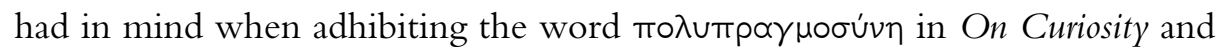
the Lives. In the second part, it explores some of the implications of the fact that On Curiosity and the Lives belong to different genres in an attempt to explain why none of the protagonists of the Lives is represented as subject to

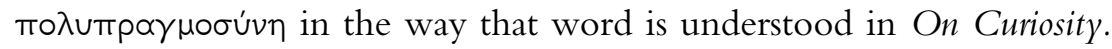

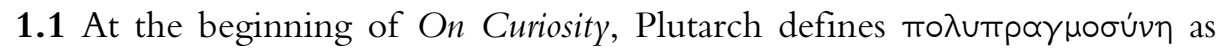
follows:

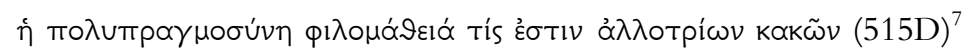

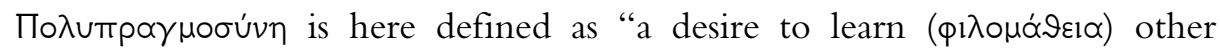

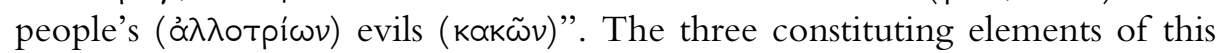
definition are given further attention in the rest of the work. In a first part $(\$ 1 \mathrm{~b}-3 \mathrm{a})^{8}$, the stress is on the polypragmon's interest in other people's affairs: polypragmones cannot bear to look into their own souls. After that, the focus is shifted towards the polypragmon's preference for evil things $(\$ 3 \mathrm{~b}-6$, esp. 516D-F, 517F, and 518A). Dubious genealogies, seduced virgins, adulterous wives, indicted processes, internecine struggles: these are the topics that carry away his interest. The third, and longest part of the work $(\$ 7-16)$ shows the polypragmōn's desire to learn 'at work': his life is completely dominated by polypragmosyne, in that he neglects his duties, is obsessively busy with searching out other people's evils, reacts impulsively or mechanically to whatever he happens to notice, and, consequently, has no control over his life. ${ }^{9}$ This last part of the work also contains the most elaborate therapy for polypragmosynē:

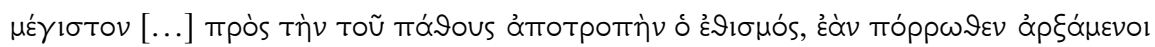

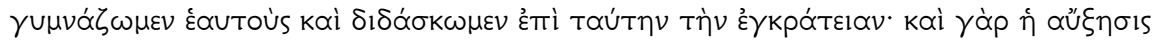

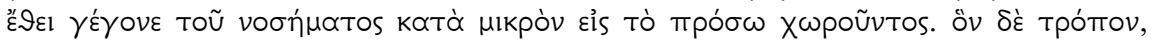

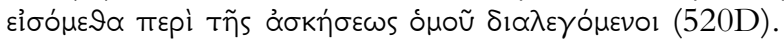

the greatest factor $[\ldots]$ to avert this affection is habituation: starting from its beginnings, to train and teach ourselves to acquire that self-control. It is, in fact, through habit that the disease has come to increase, advancing, as it did, little by

and Inglese (1996), studies by Hense, Ingenkamp, Volpe-Cacciatore, Walsh, and Inglese (1995). None of these studies, however, gave attention to the difference in use

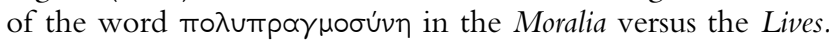

7 Unless indicated differently, for On Curiosity, all text quotations are taken from the edition of Pohlenz, all translations from Helmbold, whereas for all other ancient works, both texts and translations are taken from the Loeb Classical Library.

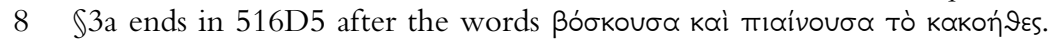

9 This is not only elaborated theoretically - the polypragmon, Plutarch states $(\mathbb{S} 12)$, is guided not by his reason but by his senses -, but also shines through gramatically, when

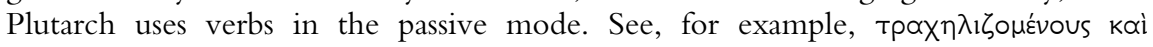

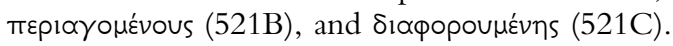


little. How this habit is acquired, we shall learn when we discuss the proper training (520D). ${ }^{10}$

From this passage, it is clear that what Plutarch has in view is not so much a

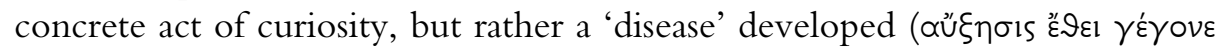

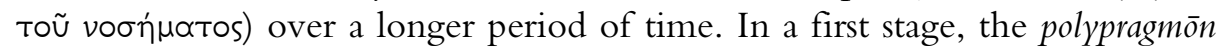
reads every inscription he encounters. Then he starts prying into other people's houses. When the disease develops further, the polypragmon wants to be around when something happens on the marketplace, is unable to resist when a successful show takes place at the theatre, when there is excitement in the stadium or the hippodrome, or when a friend invites him to come and see a (pantomimic) ${ }^{11}$ dancer or a comedian. Finally, he demands to hear and see everything that concerns himself as soon as possible.

The overall impression, then, is of a man who is 'hanging around' in town, and will stop people just in order to learn the latest news (519A), irritated if there is none.

On a more abstract level, Plutarch interprets polypragmosyne $\bar{e}$ as an affection

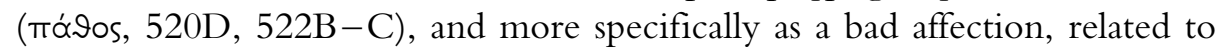

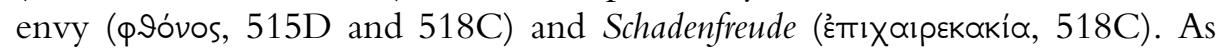
such, Plutarch vehemently pleads against it as being shameful (aíoxpóv),

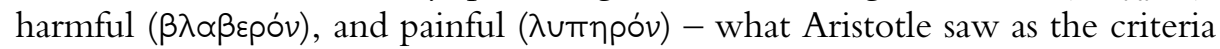
for avoidance. ${ }^{12}$ As has been shown by Ingenkamp, these criteria are of primary importance in Plutarch's Seelenheilungsschriften as well: the demonstration that the reader's behaviour meets the criteria of avoidance instead of choice, showing the danger and shame resulting from it, are to make the reader feel distressed, and thus incite him to change his behaviour. What Plutarch offers the reader with his work On Curiosity, is a therapy against polypragmosyne $\bar{e}$, comprising three stages. The first step $(\$ 1 b-3 a)$ directly urges the reader to actively examine and ameliorate his own soul. Yet as some people do not dare (oủX úmouḱvovoıv, 516C) to look into their own souls, the second remedy $(\$ 3 b-6)$ proposes nature and history as more interesting topics to direct one's attention to. Nevertheless, as nature is not bad and history not recent enough for the polypragmon, this remedy is bound to fail as well. The conclusion must be that polypragmosyne should be done away with quite radically, by thoroughly

10 I modified Helmbold's, 501 translation. See also the following note.

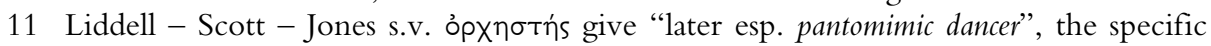
word for this kind of dancer being mavtóminos. Plutarch, however, never uses

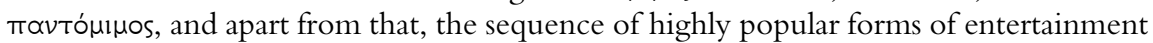

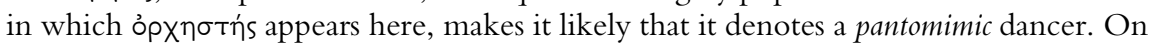
the popularity of pantomime, see Seneca, On Anger 1.20.8.

12 See Ingenkamp, 74-5. Note that the same criteria, albeit much less systematically, are already mentioned by Plato, Republic II 363e-364a. 
changing one's behaviour. The remedy proposed last in On Curiosity ( $\$ 7-16)$ therefore contains some very concrete advice for real-life situations in which people reveal their being subject to polypragmosyne

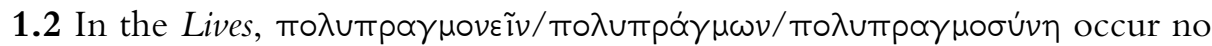
more than thirty-two times (on a total of some 115 occurences in all of Plutarch's works).

Of these already few occurences, only two apply directly to the hero of the life in question. In the first case, Camillus, asked by the Romans to come back from Ardea, says to be ready to do so if they elect him as their general, while

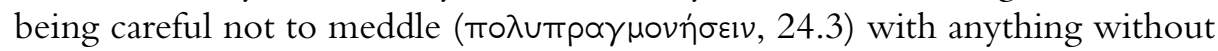
a command. ${ }^{13}$ In the other instance, Eumenes does not openly take up a standpoint in the quarrel between the soldiers and the officers after Alexander's death, explaining that it is none of his business since he is no Macedonian ( $\dot{\omega}$

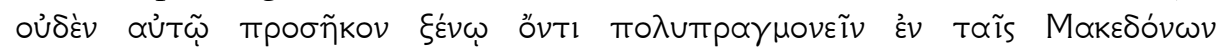

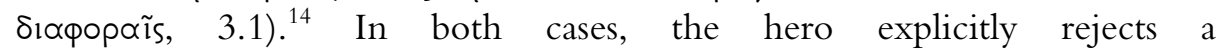

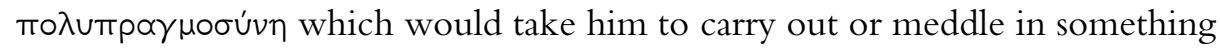
which he has no (institutional, respectively natural) reason to busy himself with.

On the other hand, the heroes of the Lives often curtail other people's

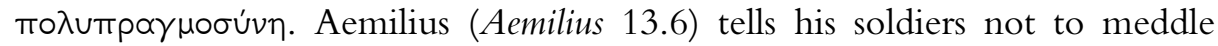
( $\pi \circ \lambda \cup \pi \rho \propto \gamma \mu о v \varepsilon \tilde{i})$ ) but to leave the war to him, and so does Pompey (Caesar 33.5) tell the people. Demetrius, on the other hand, starts a war against the Aetolians because he notices that his people obey him on expedition, but are

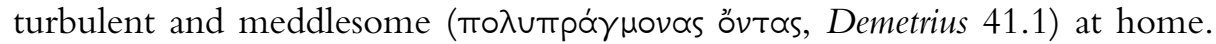
Antony gets involved in a war because of his wife Fulvia's proclivity to

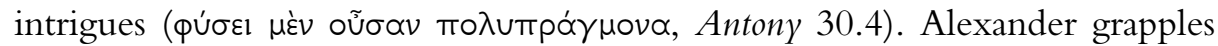
with the same problem in a better way: he honours his mother but does not

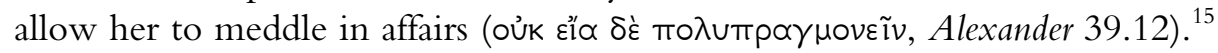
Sulla addresses the senate in order to prevent the senators from concerning

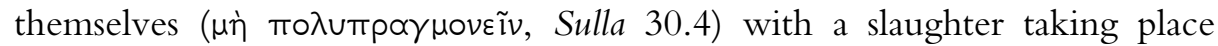
simultaneously at his command. Pompey simply bribes the people with a distribution of lands so as to make them tame and indistinctively (oủঠèv

13 A very similar case is Agis 12.3, where Plutarch talks about the limits of the ephors'

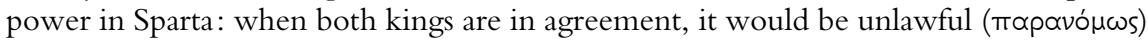
for the ephors to meddle (

14 Cf. also Eumenes 3.14: Perdiccas is there said not to interfere ( $\mu \eta \delta \dot{\varepsilon} v .$.

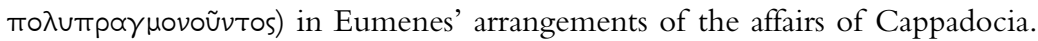

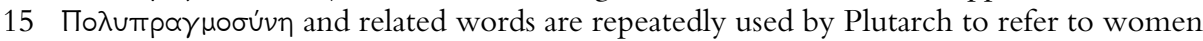
meddling in men's affairs. See Pyrrhus 29.12, Agis 7.5, and Comparison Lycurgus-Numa 3.10 . 


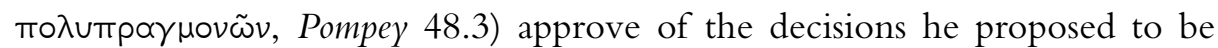
voted.

More generally, the mob is repeatedly characterised as meddlesome. Pericles, for example, takes measures in order to lighten the city of this idle and

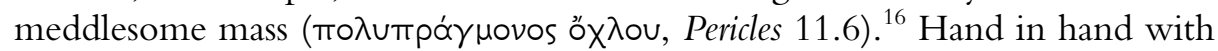
this meddlesomeness goes a tendency for revolutionary ideas, as is clear from

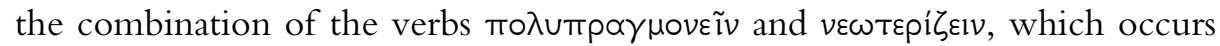
twice in the Lives (Phocion 29.5, and Artaxerxes 6.1).

What Pericles also tries to restrict, at a certain point, is the Athenians'

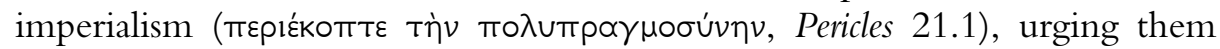
towards a more defensive policy: he foresaw that they would ruin themselves

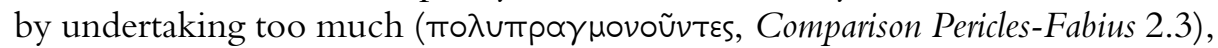

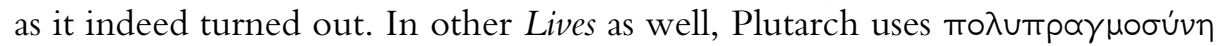
and related words to refer to imperialistic policies of various people. ${ }^{17}$

In the Life of Crassus, Vibius sends out a slave to provide Crassus with food when the latter had hidden himself in a cave. He orders the slave to put the food nearby without investigating anything, threatening to kill him in case he

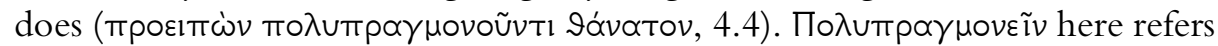
to wondering about things one should simply accept. ${ }^{18}$ Finally, there are two passages in the Lives where people are eavesdropping and purposely overhearing things which do not regard them. One of them is Caesar's barber, who

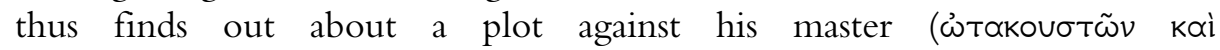

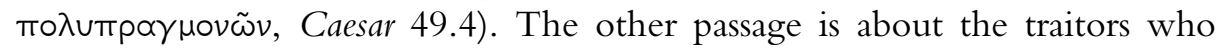
moved among the Syracusans in order to overhear other people's talks

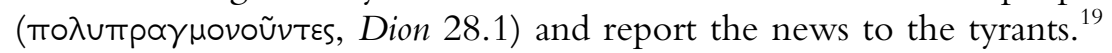

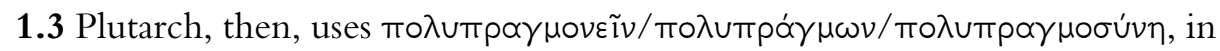
both On Curiosity and the Lives. Etymologically, the words point to busying oneself $(-\pi \rho \alpha \gamma \mu \circ v \varepsilon \tilde{v} v)$ a lot $\left(\pi \circ \lambda u_{-}\right) .{ }^{20}$ 'Busying oneself refers primarily to a physical activity, but by extension also to a mental one. 'A lot' means with

16 A similar characterisation of the mob is to be found in Coriolanus 20.3.

17 See Cimon 16.2, Sulla 5.6, and also Phocion 27.8.

18 So do the people in Pericles 23.1: although Pericles presented the people with a bill

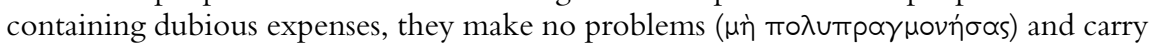
out no investigation. In the case of Rome, the nobles do not allow the multitude to

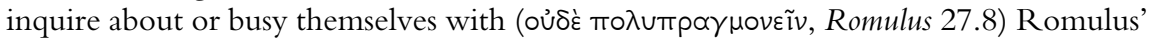
disappearance during a storm at the end of his life.

19 In a positive variant, Lycurgus encourages the young Spartans to exert social control

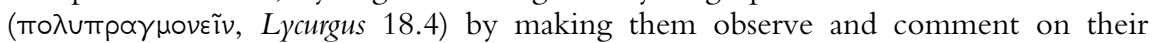

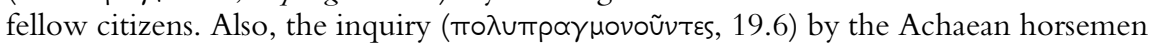
under Philopoemen's command after they had abandoned him to the enemy, is presented as justified.

20 For a short survey of its possible meanings, see also Demont, 28. 
more than one's own things or more than one is supposed to busy oneself with

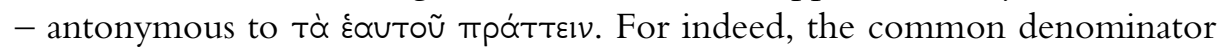
behind all uses of the word seems to be the opposition of self and others: carrying out one's own versus someone else's tasks, ruling oneself versus ruling others, self-scrutiny versus 'scientific' research or versus meddlesomeness, etc.

Yet the uses and meanings of the word in On Curiosity and the Lives differ quite thoroughly. In On Curiosity, Plutarch adhibits the words in a particular, ethical-philosophical sense: the polypragmonn is a man frequenting public places in order to get and give information about others; a man with a preference for

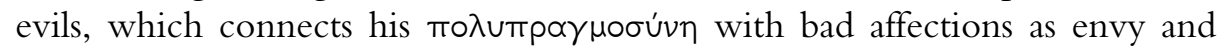

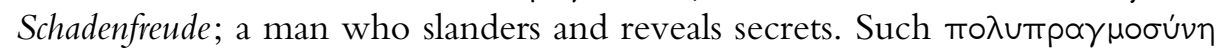
is a mental inquiry into the wrong object.

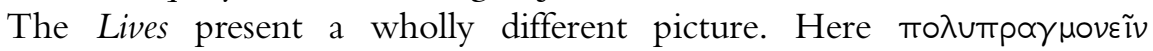

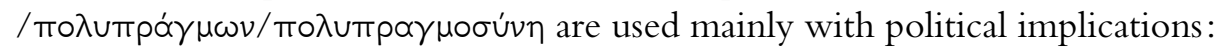
carrying out someone else's tasks, imperialism, meddling with political decisions by people who ought not to, sycophantism - these are what

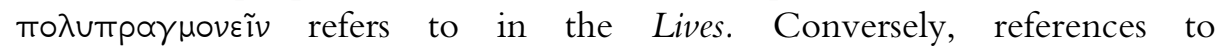

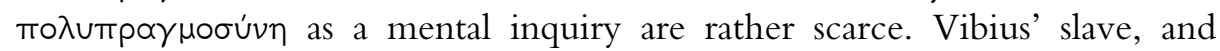
Caesar's barber are two examples. ${ }^{21}$ What also catches the eye, is that none of

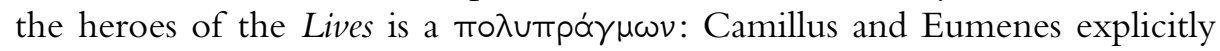
refuse to undertake an action which could be interpreted as political

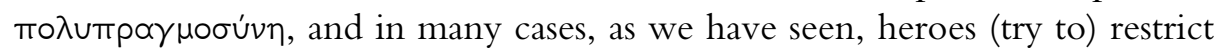

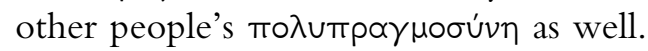

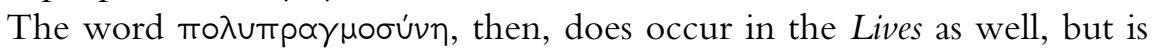
never applied to the protagonists in the sense it has in On Curiosity. Conversely, to my knowledge, none of these protagonists is described in another terminology to exhibit the characteristics of On Curiosity's polypragmōn. $^{22}$

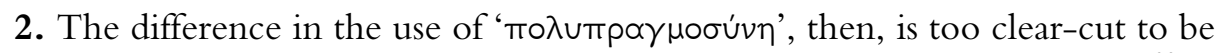
the result of pure chance. All the more so, as it is striking how few ${ }^{23}-$

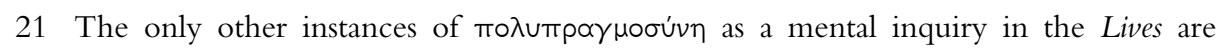
quoted in note 18 above. Note, however, that Plutarch here uses the verb

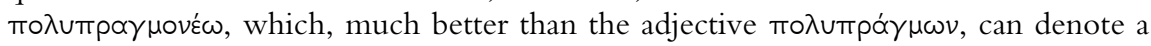
once-only instance of polypragmosyne.

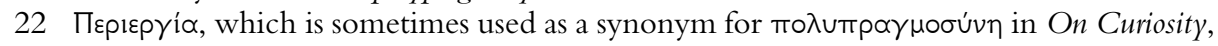
occurs but four times in the Lives, and is said about someone else than the protagonist (Pompey 55.3 and Alexander 2.9), or used in another sense (Gracchi 2.4), or, once, explicitly denied for the protagonist (Demetrius 12.8). For Plutarch's lost treatise Пepì

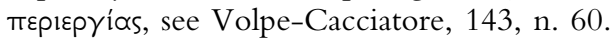

23 Apart from Odysseus and Socrates, Cyrus and Alexander are the only ones. Rusticus, on the other hand, is a contemporary example. 
compared, that is, to Plutarch's usual practice in most of the popularphilosophical writings of the Moralia - are the historical examples of either bad or good attitudes concerning the vice under discussion given in On Curiosity. ${ }^{24}$ All this begs for an explanation. More specifically, one wonders why none of the protagonists of the Lives is (represented as) a polypragmōn, although Plutarch on the one hand apparently found polypragmosyne important enough to dedicate a whole work to it, and, on the other hand, did have an eye for the vices of the protagonists of the Lives. This is the question the next pages will try to answer.

2.1 On Curiosity and the Lives are clearly different kinds of writings. In line with this, they are the heirs of different traditions. It is noteworthy that these

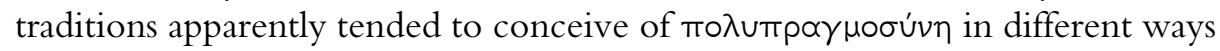
as well.

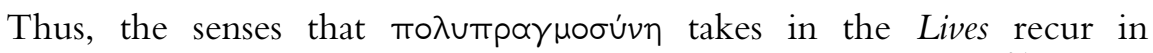
historiographical works. Herodotus (Histories 3.15.5), for example, ${ }^{25}$ applies the word to the behaviour of Psammenitus, the Egyptian king who was captured by Cambyses but, having gained admiration, enjoyed a good regime. Herodotus says of him that "had he but been wise enough to mind his own

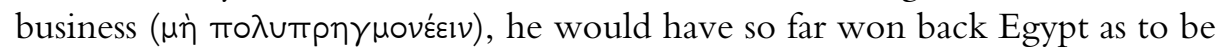
governor of it". Instead, he raised a revolt among the Egyptians, and was therefore sentenced to death. The word was also used in historiographical works to denote the interfering of one city or state in another city's or state's affairs. $^{26}$ Thus, the opponents, both internal and external, of Athens'

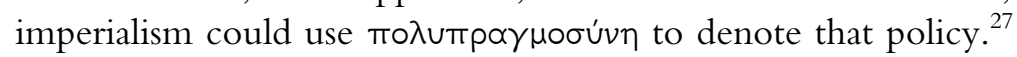

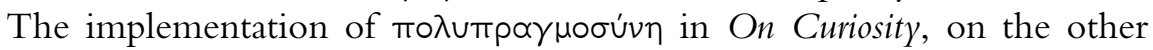
hand, may have its roots in comedy. Several new comedies now lost had

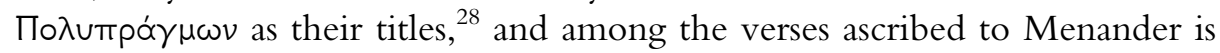
the following:

24 See also Nikolaidis (forthcoming), 4.

25 Another example can be found in Xenophon, Hellenica 1.6.3.2.

26 Although Athens is the case in point par excellence, other examples can be given as well: Polybius (e.g. Histories 2.13.3) applied the word to Rome's foreign policy, and Isocrates (Areopagiticus 80.4) to the barbarians.

27 See for example Thucydides 6.87.3, Aristophanes, Acharnians 833, and Isocrates, On Peace 26.4, 30.2, 58.7, and 108.1. Allison pointed to the fact that the word

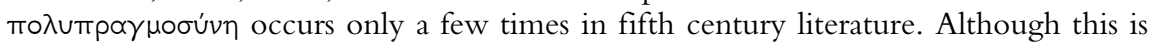
correct, the question of whether cities and people ought to interfere with others seems to have been a vexed one at the time. As a result, many scholars have discussed it. See esp. Ehrenberg, Adkins, 311-317, and Demont, esp. 191-252.

28 Inglese 1996, 16 n. 23, lists the authors. Note also that Plutarch himself in 515D inserts a comic verse reproaching the polypragmōn. 


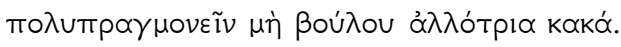

Don't inquire into other people's evils! (Monostichoi 1.583/703). ${ }^{29}$

The clearest parallel for polypragmosyne as intended in On Curiosity, however, is to be found in a passage of Philo - in an ethical passage of a philosophical work, that is. For indeed, Philo describes the worthless man (ó paũ hurrying (

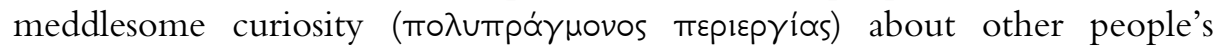

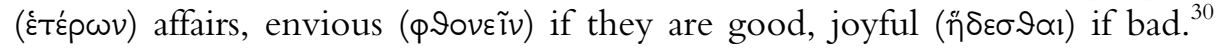

Although Plutarch, as all authors, certainly has been influenced by his own reading, to propose this as the only, or even the main, reason why he used the

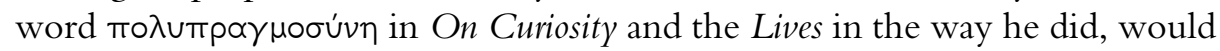
be to go back to 19th and early 20th century Quellenforschung, reducing Plutarch to and explaining him from his 'sources'. Fortunately, scholarship has gone a long way since, showing Plutarch to be much more original and autonomous than had often been assumed.

Yet on the other hand, it is true that Plutarch, to my knowledge at least, ${ }^{31}$ does not 'invent' qualities for his heroes. Theoretically, it is therefore possible that the only reason why Plutarch does not characterize any of the heroes of his Lives as a polypragmon, is that they had not been characterized as such before him. This, however, does not resolve, but only defer the problem: the question remains why they had not been represented as such before - if not by

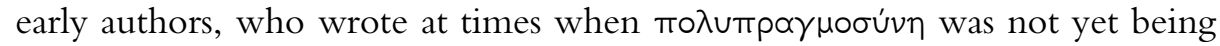
used in an ethical sense, then at least since Menander. Moreover, even if authors before him did not label it so, Plutarch could have interpreted the behaviour they ascribed to certain historical figures as polypragmosyne.

2.2 If, thus, the 'sources' offer at best a partial explanation, what else can be said that matters to our question? Why is none of the protagonists of the Lives subject to the affection (má̧os) polypragmosyne, although they all are so to other affections? What, in other words, distinguishes polypragmosyne from, say,

29 My translation. On curiosity in Menander, see Mette.

30 On Abraham, 20-21. Like Plutarch in his On Curiosity, Philo here interprets

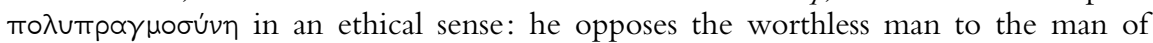
worth ( $\delta \delta$ ' $\alpha$ ' $\sigma \tau \varepsilon \tilde{I} о \varsigma)$, stresses the importance of learning to draw distinctions, and explains the interest in evil things by reference to affections. Notwithstanding, Philo did not dedicate an entire writing to the subject, nor propose any concrete solution for it, let alone a therapy enabling and teaching his readers to come to that solution.

31 Cf. Pelling 1980, and idem 1988, 284 and n. 5. 
ambition or anger ${ }^{32}$ in a way so as to make the former, contrarily to the other affections, unfit for a hero?

In On Curiosity, as was shown above, Plutarch presents the polypragmōn as a man who, for want of better things to do, loiters about in town nosing into other people's affairs, and rejoicing when these are evil. The picture Plutarch draws is not only one-sided, focussing exclusively on polypragmosyne at the expense of any other characteristics, but even caricatural. ${ }^{33}$ For indeed, the polypragmōn staged in On Curiosity is worse than any really existing person: ${ }^{34}$ continuously and exclusively focussed on other people's evils, he has no business of his own to take care of at all. As such, the polypragmonn is not realistic, does not exist. And what is more, part of On Curiosity's effectiveness depends upon this fact: ${ }^{35}$ the reader, who exhibits some of the behaviour of the polypragmōn but is, on the other hand, his better, is encouraged to distance himself even further from a figure presented in so repulsive a way. If, then, the readers of On Curiosity estimate themselves 'above' the polypragmon, then they definitely estimate the heroes of the Lives to be so, as these are not only (at least supposed to be ${ }^{36}$ real human beings, but eminent ones.

For indeed, the fact that Plutarch wrote their Life implies that they were historically important enough to make it to the annals of history, and therefore, they would have made it to the top. In order to do so, they would

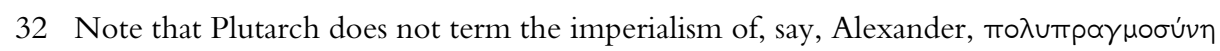
- a meaning that word could easily have in a political or military context -, but sees it as

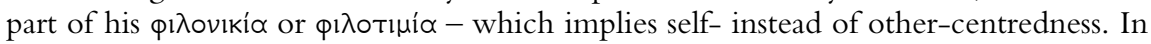

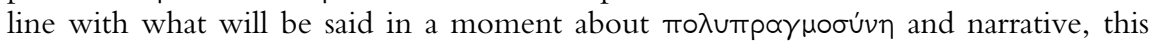
confirms that Plutarch conceives of his protagonists' imperial ambitions as (part of) their goal in life, and not as yet another aim. On ambition in the Lives, see, e.g., Frazier, Duff, 83-89, and Stadter (forthcoming).

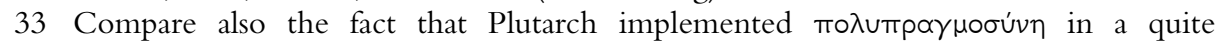
idiosyncratic way. For indeed, apart from the fact that he was the first author to

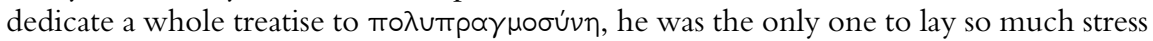

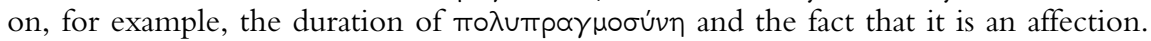

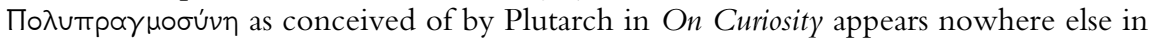
Greek literature in so elaborate a way.

34 Precisely this may have made the polypragmon such an interesting character for comedy (cf. above, n. 28), especially if one takes into account Aristotle's comments in Poetics 2, 1448a16-18 on the difference between comedy and tragedy regarding the imitated object. On this passage, see Else, 82-89.

35 What Pelling 1995 wrote in another context regarding Plutarch's ethics thus applies here as well: "There is evidently a two-way process here, with audience ready for the text, and the text affecting the audience." (p. 247).

36 For Theseus and Romulus, see Pelling 1999. 
have needed so much time and energy as to leave none for trivialities as the ones the polypragmōn goes after. This is confirmed in On Curiosity: ${ }^{37}$

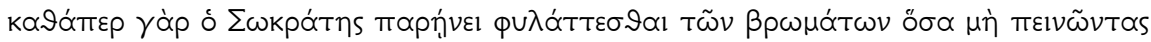

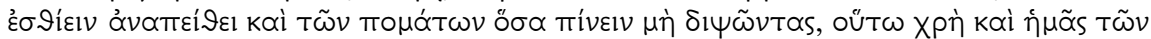

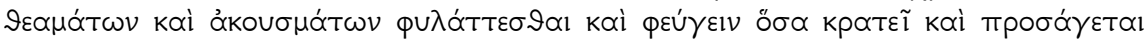

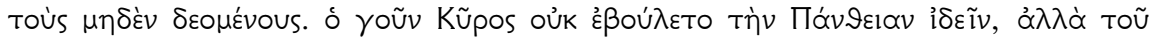

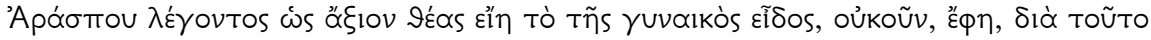

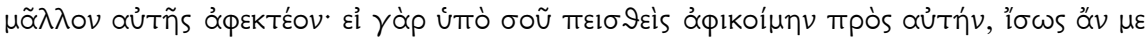

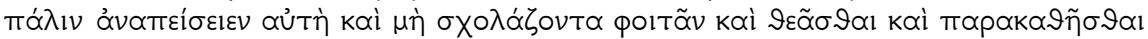

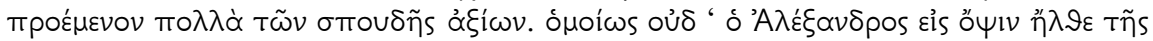

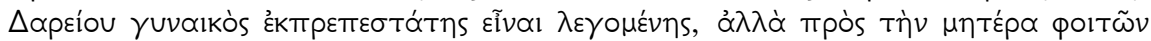

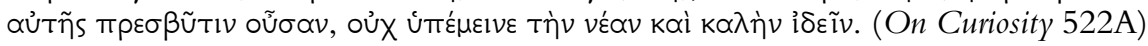

For as Socrates used to advise the avoidance of such foods as tempt us to eat when we are not hungry and such drinks as tempt us to imbibe when we are not thirsty, so we also should avoid and guard against such sights and sounds as master and attract us without fulfilling any need of ours. Thus Cyrus was unwilling to see Pantheia; and when Araspes declared that the woman's beauty was worth seeing, Cyrus said, "Then this is all the more reason for keeping away from her. For if, persuaded by you, I should go to her, perhaps she herself might tempt me, when I couldn't spare the time, to go to see her again and sit by her, to the neglect of many important matters." So too Alexander would not go to see Darius' wife who was said to be very beautiful, but although he visited her mother, an elderly woman, he could not bring himself to see the young and beautiful daughter.

Cyrus and Alexander did not go to see a beautiful woman, for fear they might

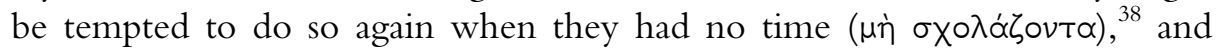
thereby neglect matters worthy of attention. Cyrus' words and Alexander's deeds reveal not only that they have more important things to do, ${ }^{39}$ but also that they are aware of this fact and live accordingly. ${ }^{40}$ The polypragmōn, on the contrary, is not taken by any serious activity. Yet the process is double-edged, and the disease self-reinforcing: from being distracted by inscriptions on one's

37 Cf. also the Comparison of Aristides and Cato, 4.2, where Plutarch, talking about poverty because of soberness, industriousness, righteousness, and braveness, writes that "it is impossible for a man to do great things when his thoughts are busy with little things"

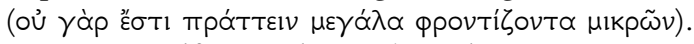

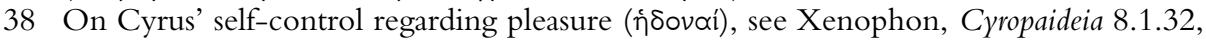
and on this passage and the importance of timing in matters of pleasure, Foucault, 69.

In his essay How to Study Poetry 31C, Plutarch gives Cyrus' behaviour towards Pantheia as an example to be followed by those who are easily enamoured. There, the stress is more on avoiding one's passions to be kindled, here, on spending time - which one may not have - at things one does not need.

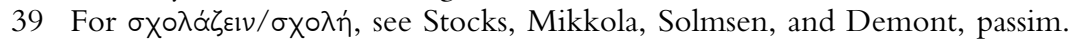

40 Odysseus, whom many readers might think to be a polypragmōn, is another example: he does indeed ask the women he sees in Hades after all kinds of things, but never forgets the aim of his descent into the underworld, nor his ultimate aim, to reach Ithaca. As a result, Plutarch presents him as an example not of a polypragmōn, but of the contrary. 
way, the polypragmon, over reacting to all stimuli indifferently, ends up having no time for better things, ${ }^{41}$ absorbed as he is by his polypragmosyne $\bar{e} .{ }^{4}$ polypragmosyne $\bar{e}$ stands in the way of the great achievements ${ }^{43}$ reached by men whose biography Plutarch would therefore want to write. The activities of the polypragmon on the one hand and of the protagonists of the Lives on the other, then, are in a certain way mutually exclusive.

2.3 On a more technical level, the narrative character - typically telling the story of a series of logically/chronologically related events ${ }^{44}$ - of Plutarch's Lives makes polypragmosyne not so suited as an affection for the protagonists. For indeed, whereas the Lives largely have a linear progression between their protagonists' birth and death, polypragmosyne as understood in On Curiosity ${ }^{45}$ by definition implies the absence of a (more or less) straight line, the polypragmōn always being distracted from what he was heading for. Plutarch indeed describes the polypragmōn as so fussy about whatever he happens to encounter, that he appears as a person loitering around without any aim, just waiting for anything (bad, preferably) to happen. ${ }^{46}$ Quite the contrary goes for the protagonists of the Lives: they have high aspirations, well-defined objectives, clear goals - as is typical not only for people who made it to the top, but also, more technically speaking, for narratives. ${ }^{47}$

The narrative of the Lives, then, supposes progression, and this progression is largely dependent on their protagonists' strivings. Whereas other affections

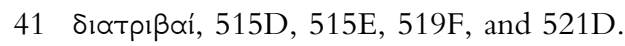

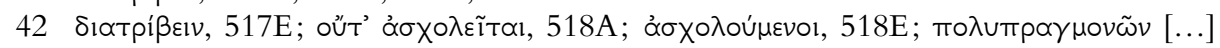

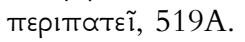

43 See, for a very clear example, Plutarch's advice to the polypragmōn to list all his achievements in $₫ 10$.

44 For a discussion of narrativity, see Van Gorp - Delabastita - Ghesquiere, 295-296, and Baldick, 165-166.

45 On Curiosity is clearly not a narrative work. Notwithstanding, it does contain some narrative anecdotes. The historical ones, as has been noted, are much less frequent, however, than in other, kindlike works of the Moralia. On the use of narrative anecdotes in non-narrative literature, see Nash. See also the next note.

46 This is not in contradiction to what was said above about Plutarch sketching the development of polypragmosyne: Plutarch does not tell the story of (part of the life of) a polypragmon, he proposes different steps of a therapy which correspond to certain acts that are typical for polypragmones in general. For example, Plutarch does not say that "after and/or because of having read inscriptions on walls, polypragmōn X turned to nosing into people's houses, and was ruined in such and such way as a result of it", but that "it is not difficult to accustom oneself to not nosing into people's houses, as that generally brings no advantages".

47 See Propp, esp. 80, Greimas, esp. 172-191, Toolan, 93-96, and Rosenboom, 25-42. 
may cross the heroes' main ambitions ${ }^{48}$ polypragmosyne does not merely cross, but ends them: the polypragmōn does not act, but merely re-act. ${ }^{49}$ As the end of ambition would, in the Lives, imply the end of progression, polypragmosyne is not suited as an affection for the narrative texts that the Lives are.

3. A double conclusion can be drawn from the foregoing. On the one hand, asking the question of why none of the protagonists of the Lives is represented

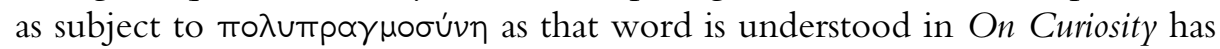
led to a better understanding of what exactly that word does mean in the latter work. More specifically, it has become clear that the polypragmon as sketched in On Curiosity is a caricature, and, moreover, that the effectiveness of the work at least partly depends upon this. Furthermore, the present study has also shown polypragmosyne to be something both 'below' the heroes of the Lives and unfit for the narrative genre that the Lives are.

On the other hand, this implies that genres may play a - sometimes major - role in determining how certain words are used, how certain ideas are evoked: making the polypragmōn a caricature was useful in order for the treatise On Curiosity to affect its readers' behaviour. The fact that certain affections can whereas other ones cannot be discussed in certain kinds of texts should, conversely, be a warning for the interpretation of 'historical truth' about people's characters: even if a protagonist of the Lives would have exhibited an aspect of the polypragmon's behaviour, polypragmosyne was not an interesting affection to be discussed in a narrative text. In case Plutarch has, in this matter, undergone heavy influence from his sources, this warning extends to these sources as well.

In line with this, it would be interesting to examine the degree up to which the fact that the Moralia and the Lives are different kinds of texts had a bearing on the ethical programme Plutarch treats and promotes, and if, for example, what has been said here about polypragmosyne goes for affections such as talkativeness and compliance as well. Do the Moralia and the Lives present the same canon of virtues? If so, to what extent did genre-conventions

48 For indeed, the fact the protagonists of the Lives are guided by their goals, does not mean that they (all) actually reach their goals, or that they cannot be deflected from pursuing it by certain affections. In fact, it is this very fact that makes them into interesting subjects for Plutarch's ethical project. Plutarch indeed renders negative characteristics as well, without, however, being malicious. See also Duff, 58-59, and Swain, 146, about Plutarch's own practice in the Lives. Anger, conversely, is an example of an affection well suited for narrative: something happens to the protagonist; the protagonist gets angry and strives for revenge; he either punishes his wrongdoer or tragically meets with disaster heroically - but in any case, there is a strong causal and temporal progression.

49 Many verbs are indeed in the passive mode. 
influence the concrete implementations in both groups of works? Or if not: what role did genres play in this? Yet not only are these different questions, answering them would also exceed by far the scope of this paper. With my contribution, however, I hope to have given an example concerning one affection, and shown what results can be expected.

\section{Bibliography}

Adkins, A.W.H. (1976), “Polupragmosune and 'Minding One's Own Business'. A Study in Greek Social and Political Values", CPh 71: 301-327.

Alexiou, E. (1999), “Zur Darstellung der ópyń in Plutarchs Bíoı”, Philologus 143: $101-$ 13.

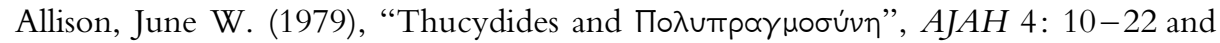
$157-158$.

Baldick, C. (2001), The Concise Oxford Dictionary of Literary Terms, Oxford.

Demont, P. (1990), La cité grecque archaïque et classique et l'idéal de tranquillité (Collection d'études anciennes. Série grecque 118), Paris.

Duff, T.E. (1999), Plutarch's Lives. Exploring Virtue and Vice, Oxford.

Dumortier, J. - Defradas, J. (1975) (edd.), Plutarque. Oeuvres Morales. Tome VII, Première Partie (Budé), Paris.

Ehrenberg, V. (1947), "Polypragmosune. A study in Greek Politics", JHS 67: 46-67. Else, G. F. (1967), Aristotle's Poetics. The Argument, Cambridge (Mass.).

Foucault, M. (1984), Histoire de la sexualité. 2. L'usage des plaisirs, Paris.

Frazier, Françoise (1988), “A propos de la 'philotimia' dans les Vies. Quelques jalons dans l'histoire d'une notion", RPh 62: 109-127.

Greimas, A.J. (1966), Sémantique Structurale. Recherche de méthode (Langue et Language), Paris.

Helmbold (1993=1939) (ed.), Plutarch. Moralia, Volume VI (Loeb), Cambridge MA and London.

Hense, O. (1890), “Ariston bei Plutarch”, RhM 45: 541-554.

Ingenkamp, H.G. (1971), Plutarchs Schriften über die Heilung der Seele, Göttingen.

Inglese, L. (1995), "Plutarco, De curiositate 517A", in Italo Gallo (ed.), Seconda miscellanea filologica, Napoli, 159-166.

(1996), Plutarco. La curiosità (CPM 24), Napoli.

Jones, C.P. (1966), “Towards a Chronology of Plutarch's Works”, JRS 56: 61-74.

Mette, H.J. (1962), "Die Periergia bei Menander", Gymnasium 69: 398-406.

Mikkola, E. (1958), "Scholè bei Aristoteles", Arctos n.s. 2: 68-87.

Nash, C. (ed.) (1990), Narrative in Culture. The uses of storytelling in the sciences, philosophy and literature, London.

Nikolaidis, A. G. (1991), "Plutarch's Contradictions”, CEM 42: 153-186.

(forthcoming), "Plutarch's Minor Ethics. Some Remarks on De Garrulitate, De Curiositate, and De Vitioso Pudore", in L. Van der Stockt, (ed.), Virtues for the People. Plutarch and his Era on Desirable Ethics. (Acts of the conference held in Delphi, September 1-5 2004).

Paton, W.R. - Pohlenz, M. - Sieveking, W. (1972=1929) (eds.), Plutarchi

Moralia. Vol. III (Teubner), Leipzig. 
Pelling, C.B.R. (1980), "Plutarch's Adaptation of His Source-Material”, JHS 100: 127-140 - Reprinted in id. (2002), Plutarch and History. Eighteen Studies, London, $91-115$.

(1988), “Aspects of Plutarch's Characterization", ICS 13.2: 257-274

- Reprinted in id. (2002), above, London, 283-300.

(1995), "The Moralism of Plutarch's Lives", in Innes, D.C. - Hine, H. - Pelling, C.B.R. (edd.), Ethics and Rhetoric. Classical Essays for D. Russell on his Seventy-Fifth Birthday, Oxford - Reprinted in id. (2002), above, 237-252.

(1999), "Making Myth Look Like History'. Plutarch's Theseus-Romulus", in PérezJiménez, A. - García López, J. - Aguilar, R.M. (edd.), Plutarco, Platón y Aristóteles. Actas del V Congreso Internacional de la I.P.S., Madrid - Cuenca, 4-7 de mayo de 1999, Madrid - Reprinted in id. (2002), above, 171-195.

Pettine, E. (1977), Plutarco. La curiosità. Introduzione, Testo, Versione e Note, Salerno.

Propp, V. (1968), Morphology of the Folktale (First Edition Translated by Laurence Scott with an Introduction by Svatava Pirkova-Jakobson, Second Edition Revised and Edited with a Preface by Louis A. Wagner, New Introduction by Alan Dundes), Austin and London.

Rosenboom, T. (2002), Aanvallend Spel. Vier Lezingen over Schrijven, Amsterdam.

Solmsen, F. (1964), "Leisure and Play in Aristotle's Ideal State", RhM 107: 192-220.

Stadter, P.A. (forthcoming), "Competition and its Costs. Philonikia in Plutarch's Society and Heroes", in Van der Stockt, L. (ed.).

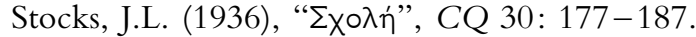

Swain, S. (1996), Hellenism and Empire. Language, Classicism, and Power in the Greek World, AD 50-250, Oxford.

Toolan, M.J. (1988), Narrative. A Critical Linguistic Introduction (Interface), London.

Van Gorp, H. - Delabastita, D. - Ghesquiere, R. (1998), Lexicon van Literaire Termen, Zevende, herziene druk, Groningen and Deurne.

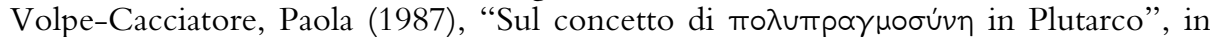

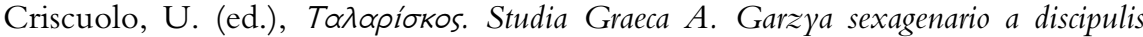
oblata, Napoli, 129-145.

Walsh, P.G. (1988), "The rights and wrongs of curiosity (Plutarch to Augustine)", GER 35: 73-85.

Ziegler, K. (1951), "Ploutarchos", in RE XXI.1, Stuttgart. 